\title{
EVALUATION OF THE FODDER STOCKS FOR THE PRZEWALSKI HORSE EQUUS FERUS PRZEWALSKII ON THE «PRE-URAL STEPPE»PLOT OF THE ORENBURG STATE NATURE RESERVE
}

\author{
Tatjana L. Zharkikh ${ }^{1}$, Lyubov G. Linerova ${ }^{2}$ \\ ${ }^{1}$ Orenburg Reserves, Russia \\ e-mail: russian969@yandex.ru \\ ${ }^{2}$ Orenburg State Pedagogical University, Russia \\ e-mail: linerova.liuba2009@yandex.ru
}

Received: 30.09 .2016

\begin{abstract}
In 2015 the Federal Government Funded Institution «Orenburg Reserves» started the Programme of Establishing of a Semi-Free Population of the Przewalski Horse at the Orenburg Reserve on the territory of the steppe area «PreUral Steppe». In 2014-2015 a pilot research was carried out to select the location for construction of the Centre of the re-introduction of the Przewalski horse. To evaluate the fodder stocks in the selected area we developed criteria for evaluating the vegetation condition under the influence of grazing. The results have shown that within the boundaries of the «Pre-Ural Steppe» plot it is most rational to place the Centre of the re-introduction of the Przewalski horse at the natural landmark Kursay. In 2015, the fodder stocks here ranged from $14 \mathrm{dt} / \mathrm{ha}$ (decitonne per hectare) in April to $30 \mathrm{dt} / \mathrm{ha}$ in September. Moreover, the grass cover vegetation here mostly consisted of species, well-grazed by Przewalski horse, particularly grasses, a significant number of legumes and well-grazed forbs. In the future, this area requires constant monitoring of the vegetation condition under the influence of the Przewalski horse grazing, with the following evaluation criteria: 1) the overall productivity of the plant mass; 2) the combination of well-grazed and ungrazed plant species in dynamics.
\end{abstract}

Key words: Equus ferus przewalskii, forage capacity, Orenburg Reserves, Orenburg State Nature Reserve, Przewalski horse.

\section{Introduction}

The Federal Government Funded Institution "The Joint Directorate of State Nature Reserves «Orenburg» and «Shaitan Tau»" includes two Nature Reserves in the Orenburg region of Russia: the State Nature Reserve «Shaytan-Tau» (within Kuvandyksky district) and the Orenburg Reserve (within Pervomaysky district, Belyaevsky district, Kuvandayksky district, Svetlinsky district, Akbulaksky district). In 2015 the «Orenburg Reserves» started the Programme of Establishing of a Semi-Free Population of the Przewalski Horse at the Orenburg Reserve on the territory of the steppe area «Pre-Ural Steppe» (Bakirova \& Zharkikh, 2015, 2016). Within the UN Development Program, the Global Environment Facility 00072294 «Improving the coverage and management efficiency of protected areas in the steppe biome of Russia» a pilot research was carried out to select the location for construction of the Centre of the re-introduction of the Przewalski horse. It was necessary to evaluate the fodder stocks in the area, selected for acclimatisation of imported groups - founders of the new Przewalski horse (Equus ferus przewalskii Groves, 1986) population - and to develop criteria for the vegetation condition evaluation under the influence of grazing.

\section{Material and Methods}

The first reintroduction of the Przewalski horse on protected areas in Russia took place on the «Pre-
Ural Steppe» plot, $165.38 \mathrm{~km}^{2}$ in area. In July 2014 and in April 2015 an overall visual evaluation of this area was carried out to select the location for the Centre of the re-introduction of the Przewalski horse.

After the spot for the Centre infrastructure had been determined, in 2015 a fodder stocks studies was held for the selected area. There were 4 expeditions undertaken to study the vegetation: in April, May (before the construction of acclimatisation corrals), July and September (inside the corrals). The GPS co-ordinates of the extreme western and eastern boundaries of acclimatisation corrals are: $\mathrm{N} 51^{\circ} 09^{\prime} 51.0^{\prime \prime}$ E $56^{\circ} 06^{\prime} 09.2^{\prime \prime}$. Characteristics of vegetation are provided according to the classification by E.M. Lavrenko (1940, 1956).

The forage phytomass was studied by cutting the vegetation at a height of $3-4 \mathrm{~cm}$ above the ground (grazing simulation) on an area of about $0.25 \mathrm{~m}^{2}$ (in total 45 recorded spots). The cut vegetation was divided into economic and biological groups: grasses, legumes, well-grazed forbs, ungrazed and avoided by Przewalski horse plants, dead grass. Then they were first air-cured and then oven dried at a temperature of $85^{\circ} \mathrm{C}$ till constant mass and weighed. To determine the forage amount, consumed by the Przewalski horse, and palatability of plants we used the Biosphere Reserve «Askania Nova» research data (Zharkikh \& Yasynetska, 2009; Pozdnyakov et al., 2011). Since the amount of consumed forage de- 
pends on its quality, season of the year, and on the sex, age, weight and condition of the animal - we took an average value of $10 \mathrm{~kg} /$ individual / day to determine the allowable pasture load for this study.

Plants were determined according to the following references (Stankov \& Taliev, 1949; Ryabinin \& Knyazev, 2009; Ryabinin et al. 2011, 2013; Flora of the European part of the USSR, 1974-1987; Siberian Flora, 1988-1997; Flora of the USSR, 19341960; Cherepanov, 1995).

\section{Results and Discussion}

SELECTION OF THE PLOT FOR ACCLIMATISATION INFRASTRUCTURE CONSTRUC-

TION. The basic criteria for the Centre of the re-introduction location choice were the relative homogeneity of the vegetation at a large enough area (no less than $10 \mathrm{~km}^{2}$ ), absolute predominance of well-grazed plant species and families, mainly grasses, and a welldeveloped herbage: projective cover and its height.

The natural landmark Kursay was chosen for the acclimatisation corrals construction on the basis of visual comparison of different areas, and because local hayfields are considered to be the best in the «Pre-Ural Steppe».

The length of the plot (within the reserve) makes approximately $10 \mathrm{~km}$, the difference in elevation ranges between 300 and $190 \mathrm{~m}$ from east to west. The width at the widest part makes about $4.5 \mathrm{~km}$. At the bottom here runs a dried-up creek bed (ravine Kursay), filled in when snow melts and by rain. The approximate GPS co-ordinates of the plot within the reserve are: N 51 $09^{\prime} 02.89^{\prime \prime}$ E $56^{\circ} 05^{\prime} 26.71^{\prime \prime}$; N 51 ${ }^{\circ} 11^{\prime} 30.97^{\prime \prime}$ E 56 05'42.31"; N 51 $09^{\circ} 24.35^{\prime \prime}$ E 56 $16^{\circ} 41.54^{\prime \prime}$.

The slopes of the plot are asymmetric: the slope of the southern exposure is shorter and steeper, its length makes $400-700 \mathrm{~m}$, the difference in elevation is $25-35 \mathrm{~m}$. The feed value of the slope vegetation is extremely low - the projective cover is less than $50 \%$ with the height of 5-20 cm. There are very few areas with a predominance of grass formations, saline soil spots are abundant here and dominated by species of the family Asteraceae (Artemisia absinthium L., A. austrica Jacq., Tanacetum vulgare L., T. millefolium (L.)Tzvel., Achillea nobilis L., A. millefolium L., Erigeron canadensis L.), family Brassicaceae (Lepidium perfoliatum L., Thlaspi arvense L., Sisymbrium polymorphum (Murr.) Roth), family Polygonaceae (Polygonum aviculare L.). Species of the family Poaceae are extremely rare, it is primarily, Stipa capillata L., S. lessingiana Trin. et Rupr., Stipa zalesskii Wilensky, Festuca pratensis Huds., Bromopsis inermis (Leyss.) Holub; there are separate bunches of plants and sporadic specimens of Poa transbaicalica Roshev, P. bulbosa L., Agro- pyron pectinatum (Bieb.) Beauv., Elytrigia repens (L.) Nevski s.l.

The northern slope is more gentle; its total length is between 1.5 and $4.0 \mathrm{~km}$. The form is convex-concave: the length at the top makes 500-800 $\mathrm{m}$, the elevation difference is between $15-25 \mathrm{~m}$, at the bottom - the gradient makes 5-20 m, the slope vegetation is typical for fescue-feather grass steppes with xeromesophilic grasses. At the top, in the less moisturized part, the herb cover is less developed and sparse. Dominant species for the family Poaceae are Stipa lessingiana, S. pennata L., S. dasyphylla (Lind.) Trautv., S. pulcherrima C. Koch., S. zalesskii, Festuca valesiaca Gaud. The projective cover hovers around the value of $50 \%$, the average height of the vegetation in the areas of grass formations makes $15-25 \mathrm{~cm}$.

The floristic composition is an important characteristic of phytocenoses; it is the result of a longterm selection of species, capable of growing in a given environment (Rabotnov, 1978). The flora of the studied region incorporates more than 300 species of vascular plants, belonging to 57 families. Angiosperms make the basic number of species here; more than $90 \%$ of them belong to the family Poaceae and Asteraceae. The investigated area is dominated by wormwood-grass associations. There were registered Agropyron pectinatum - Artemisia austrica and Poa tranbaicalica-Artemisia austrica associations.

The rest of the slope has a much better developed herbage. The mid-slope is covered mainly with fescue-feather grass formations where the following plant species dominate: Stipa lessingiana, $S$. pennata, S. dasyphylla, S. pulcherrima, S. zalesskii, Festuca valesiaca; also common are Poa transbaicalica, Agropyron pectinatum and A. desertorum (Fisch. ex Link) Schult. Species such as Stipa capillata, Elytrigia repens, Psathyrostachys juncea (Fisch.) Nevski are very rare. Species of the family Fabaceae (an important source of protein for lactating mares) are rather spread: Vicia cracca L., Medicago sativa L., various kinds of milkvetch: Astragalus testiculatus Hfll., A. macropus Bunge., A. onobrychis L. and others; abundant well-grazed forbs: Falcaria vulgaris Bernh., Eryngium planum L., Galium ruthenicum Willd. The projective cover makes $70-80 \%$, vegetation height $20-35 \mathrm{~cm}$. There are areas of saline soils, but their total area (visually) makes about $15 \%$ of the forb-grass formations.

The lower part and the bottom of the plot are covered with better developed herbage: it is 40-60 $\mathrm{cm}$ high and the projective covering here reaches 90-100\%, species have greater diversity, although the proportion of well-grazed species is lower.

The total area of the largest, more or less homogeneous area forb-fescue-feather grass as- 
sociation in the natural landmark Kursay makes approximately $20-25 \mathrm{~km}^{2}$, while the western part of the plot has a significant number of shrubs, mostly, Caragana frutex (L.) C. Koch, Spiraea crenata L., S. hypericifolia L., forming a shrub steppe (visually about $3-5 \mathrm{~km}^{2}$ ).

DETERMINATION OF FORAGE CAPACITY. The grassland of this plot is rather heterogeneous; with all the diversity of plant communities, they can be divided into two groups to evaluate the suitability of the Przewalski horses' habitat. The first group of communities (forb-grass association) is dominated by grasses and other well-grazed plants; the second group is made by plants, growing on saline soils. Table 1 shows the main characteristics of the first group of fodder stock plant communities.

The forb-grass associations areas are dominated by well-grazed species, the share of avoided and ungrazed species here makes less than a half (Table 2).

Cut hay in April, prior to the beginning of the active vegetation, consisted almost entirely of low- nutrient dead grass; species available for grazing referred to the family Poaceae: Stipa capillata, Festuca valesiaca, Agropyron pectinatum, Poa transbaicalica, Koeleria cristata (L.) Pers., Poa bulbosa L., Bromopsis inermis, species of the family Asteraceae: Artemisia dracunculus L., A. absinthium L., A. austriaca Jacq., A. pontica L., A. vulgaris L., and ungrazed by the Przewalski horse Achillea millefolium L. and A. nobilis L.

In May and July, the possibility to determine results of the hay cutting into factions appeared: grasses, legumes, well-grazed forbs and ungrazed species, dead grasses (Tables 3, 4)

The productivity of the saline soils vegetation ranged from 3.0 to $13.5 \mathrm{dt} / \mathrm{ha}$, although there were a sufficient share of avoided and ungrazed species (Table 5). Palatable species here include Bromopsis inermis, Stipa capillata, although the Przewalski horse avoids them if there are more nutritious plant species available. These species indicate a significant pasture load in a given territory before nature reserve creation.

Table 1. Fodder stock evaluation of grass vegetation in the valley Kursay

\begin{tabular}{|l|c|c|c|c|c|c|c|c|c|c|}
\hline \multirow{2}{*}{$\begin{array}{c}\text { Date of hay } \\
\text { cutting }\end{array}$} & \multirow{2}{*}{$\mathrm{n}$} & \multicolumn{9}{|c|}{ Characteristics } \\
\cline { 3 - 12 } & & \multicolumn{2}{|c|}{ Crop yield, dt/ha } & \multicolumn{2}{c|}{ Vegetation height, $\mathrm{cm}$} & \multicolumn{4}{c|}{ Projective cover, \% } \\
\cline { 3 - 12 } & $\overline{\mathrm{x}} \pm \mathrm{S} \overline{\mathrm{x}}$ & $\min$ & $\max$ & $\overline{\mathrm{x}} \pm \mathrm{S} \overline{\mathrm{x}}$ & $\min$ & $\max$ & $\overline{\mathrm{x}} \pm \mathrm{S} \overline{\mathrm{x}}$ & $\min$ & $\max$ \\
\hline 26.04 & 10 & $14.5 \pm 1.2$ & 7.6 & 21.5 & $32.3 \pm 3.3$ & 20.0 & 55.0 & $71.3 \pm 6.3$ & 40.0 & 100.0 \\
\hline 19.05 & 10 & $22.3 \pm 2.0$ & 14.2 & 30.9 & $31.5 \pm 3.3$ & 20.0 & 55.0 & $81.0 \pm 5.0$ & 50.0 & 100.0 \\
\hline 17.07 & 13 & $28.3 \pm 2.8$ & 15.6 & 43.5 & $33.0 \pm 2.8$ & 20.0 & 50.0 & $90.0 \pm 4.0$ & 60.0 & 100.0 \\
\hline 24.09 & 12 & $30.1 \pm 1.8$ & 20.9 & 39.1 & $43.0 \pm 3.3$ & 30.0 & 60.0 & $87.0 \pm 3.8$ & 65.0 & 100.0 \\
\hline
\end{tabular}

Note: $\overline{\mathrm{x}}$ - arithmetic average, $\mathrm{S} \overline{\mathrm{x}}$ - standard error, $\min$ - minimum characteristic value, max - maximum characteristic value

Table 2. Assessment of species on the plots with forb-grass plant associations according to Przewalski horse's preferences

\begin{tabular}{|c|c|c|c|c|c|}
\hline \multirow{2}{*}{$\begin{array}{c}\text { Species } \\
\text { abundance }^{*}\end{array}$} & \multicolumn{4}{|c|}{ Economic-biological vegetation groups } & \multirow{2}{*}{ Total } \\
\hline & well-grazed & avoided & ungrazed & uncertain palatability & \\
\hline 5 & 11 & - & - & 2 & 13 \\
\hline 4 & 8 & 1 & 2 & 2 & 13 \\
\hline 3 & 11 & - & 4 & 2 & 17 \\
\hline 2 & 12 & 3 & 15 & 6 & 36 \\
\hline 1 & 9 & 7 & 12 & 7 & 35 \\
\hline Total & 51 & 11 & 33 & 19 & 114 \\
\hline
\end{tabular}

Note: Abundance determination according to N. Ashikhmina: 1 point - a single specimen of this species registered at the experimental plot; 2 points - specimens are very rare and unevenly distributed; 3 points - specimens occur sporadically throughout the examined plot; 4 points - species is abundant; 5 points - species predominates, specimens often coalesce aboveground parts, forming thickets (background of the association).

Table 3. Productivity of different groups of vegetation on the plots with forb-grass plant associations in the valley Kursay in May, dt/ha

\begin{tabular}{|l|c|c|c|c|c|}
\hline \multirow{2}{*}{ Characteristics } & \multirow{2}{*}{ Total } & \multicolumn{4}{|c|}{ Economic-biological vegetation groups } \\
\cline { 3 - 6 } & & grasses & legumes & well-grazed forbs & ungrazed \\
\hline$\overline{\mathrm{x}} \pm \mathrm{S} \overline{\mathrm{x}}$ & $22.3 \pm 2.0$ & $21.5 \pm 2.0$ & $0.2 \pm 0.1$ & $0.8 \pm 0.2$ & $0.3 \pm 0.1$ \\
\hline $\min$ & 14.2 & 12.6 & 0.0 & 0.0 & 0.0 \\
\hline $\max$ & 30.9 & 29.9 & 0.3 & 2.3 & 0.7 \\
\hline
\end{tabular}

Note: $\overline{\mathrm{x}}$ - arithmetic average, $\mathrm{S} \overline{\mathrm{x}}$ - standard error, $\min$ - minimum characteristic value, max - maximum characteristic value 
Table 4. Productivity of different groups of vegetation on the plots with forb-grass plant associations in the valley Kursay in June, dt/ha

\begin{tabular}{|c|c|c|c|c|c|c|c|}
\hline \multirow{2}{*}{ Characteristics } & \multirow{2}{*}{ Total } & \multicolumn{5}{|c|}{ Economic-biological vegetation groups } \\
\cline { 3 - 8 } & & grasses & legumes & $\begin{array}{c}\text { well-grazed } \\
\text { forbs }\end{array}$ & avoided forbs & ungrazed & dead grasses \\
\hline$\overline{\mathrm{x}} \pm \mathrm{S} \overline{\mathrm{x}}$ & $28.3 \pm 2.8$ & $22.2 \pm 2.4$ & $1.3 \pm 0.6$ & $1.7 \pm 0.6$ & $0.1 \pm 0.1$ & $0.4 \pm 0.2$ & $1.4 \pm 0.4$ \\
\hline $\min$ & 15.6 & 13.4 & 0.0 & 0.0 & 0.0 & 0.0 & 0.0 \\
\hline $\max$ & 43.5 & 38.4 & 5.5 & 5.7 & 0.9 & 2.1 & 4.3 \\
\hline
\end{tabular}

Note: $\overline{\mathrm{x}}$ - arithmetic average, $\mathrm{S} \overline{\mathrm{x}}$ - standard error, $\min$ - minimum characteristic value, $\max$ - maximum characteristic value

Table 5. Assessment of species in saline plots according to Przewalski horse preferences

\begin{tabular}{|c|c|c|c|c|c|}
\hline \multirow{2}{*}{$\begin{array}{c}\text { Species } \\
\text { abundance* }\end{array}$} & \multicolumn{4}{|c|}{ Economic-biological vegetation groups of } & \multirow{2}{*}{ Total } \\
\cline { 2 - 5 } & well-grazed & avoided & ungrazed & uncertain palatability & \\
\hline 5 & 2 & 1 & 3 & 2 & 8 \\
\hline 4 & 3 & - & 2 & 2 & 7 \\
\hline 3 & 3 & 1 & 4 & 2 & 12 \\
\hline 2 & 4 & 1 & 5 & 2 & 9 \\
\hline 1 & 3 & 2 & 2 & 8 & 44 \\
\hline Total & 15 & 5 & 16 & - & 8 \\
\hline
\end{tabular}

Note: Abundance determination according to $\mathrm{N}$. Ashikhmina: 1 point - a single specimen of this species registered at the experimental plot; 2 points - specimens are very rare and unevenly distributed; 3 points - specimens occur sporadically throughout the experimental plot; 4 points - species is abundant; 5 points - species predominates, specimens often coalesce above-ground parts, forming thickets (background of the association).

Based on these results the maximum permissible pasture load for the acclimatisation corrals was calculated.

Each corral has an area of $0.45 \mathrm{~km}^{2}$, saline soils occupy about $15 \%$ of the east corral, and about $20 \%$ of the west one. The productivity of the remaining areas with high-quality fodder is virtually the same in both corrals: $28.7 \pm 1.9$ and $27.9 \pm$ $5.7 \mathrm{dt} / \mathrm{ha}$ in July and $30.1 \pm 3.8$ and $30.1 \pm 0.5 \mathrm{dt} /$ ha in September.

If we evaluate the fodder stock only in terms of grazed species (grasses, legumes, grazed forbs) excluding the vegetation of unproductive saline soils, the fodder stock in each corral makes approximately 100 tons in summer and about 52 tons in winter. According to B.D. Abaturov (1979), the steppe vegetation can withstand without prejudice to both current and subsequent productivity alienation of about $50-55 \%$ of the top. Since it is at the moment for the «Pre-Ural Steppe» plot impossible to say how much of the plant mass is alienated by other herbivores species (insects, rodents, lagomorphs), we can reduce the permissible alienation to $35 \%$. Thus, if the Przewalski horse adult specimens' consumption makes about 3.6 tons of vegetation per year, each acclimatisation corral can host 5-6 individuals in winter and up to 10 individuals in summer without damaging the vegetation cover.

\section{Conclusion}

The study showed that the natural landmark Kursay makes a perfect spot for the Centre of the re-introduction of the Przewalski horse within the area of the «Pre-Ural Steppe». The middle part of the northern exposure slope is optimal for the construction of acclimatisation corrals for the Przewalski horses, both in fodder and weather conditions - in winter the slope will be a less snowy than the bottom and, the tip of the slope will protect the corrals from southeast winds prevailing in winter.

In the year of study, the fodder stock at the investigated plot ranged from $14 \mathrm{dt} / \mathrm{ha}$ at the beginning of the vegetation up to $30 \mathrm{dt} / \mathrm{ha}$ at the end of the season, moreover the herbage cover was completely dominated by well grazed plant species, mainly grasses. Considering that the plot includes areas without Przewalski horse's vegetation and that there are other herbivorous species in the reserve, the allowable number of Przewalski horses, living at the plot ranges from 200 to 250 individuals. However, we must take into account the social structure of this species the relatively small herds of natural populations and their habit to maintain an intergroup distance (Boyd, Houpt, 1994) can make animals to disperse throughout the «Pre-Ural steppe» area, so the population density may turn much lower than the fodder stocks allow. 
In future, it is necessary to maintain a constant monitoring of the vegetation condition under the influence of the Przewalski horse's grazing. Taking into account the above, the evaluation criteria should be 1) the overall productivity of the plant mass; 2) the dynamics of the ratio between well-grazed and ungrazed species.

\section{References}

Abaturov B.D. 1979. The bioproduction process in terraneous ecosystems (by the example of pasture type ecosystems). Moscow: Nauka. 128 p. [In Russian]

Bakirova R.T., Zharkikh T.L. 2015. The first stage of the reintroduction of the Przewalski horse at the Orenburg Reserve. The preparation of infrastructure. Steppe Bulletin 45: 62-64. [In Russian]

Bakirova R.T., Zharkikh T.L. 2016. The first stage of the project on the re-introduction of the Przewalski horse to the Orenburg Reserves. II. The transportation of the first group of founders of the population. Steppe Bulletin 46: 45-49. [In Russian]

Boyd L.E., Houpt K.A. (eds). 1994. Przewalski's horse: the history and biology of an endangered species. Albany: State University of New York Press. 313 p.

Cherepanov S.K. 1995. The vascular plants of Russia and neighbouring countries (the former USSR). St. Petersburg. 992 p. [In Russian]

Lavrenko E.M. 1940. Steppes of the USSR. In: Flora of the USSR. Vol. 2. Moscow, Leningrad. P. 1-265. [In Russian]

Lavrenko E.M. 1956. Steppes and agricultural lands at the site of steppes. In: Flora of the USSR: the explanatory text to "The geobotanical map of the USSR». Scale: 1:4000000. Vol. 2. Moscow; Leningrad. P. 595-730. [In Russian]
Pozdnyakova M.K., Zharkikh T.L., Yasinetskaya N.I., Kolesnikov M.P. 2011. Quantitative estimation of nutrition of free-ranging group of Przhewalskii horse (Equus przewalskii) in steppe habitat (Askania-Nova Reserve). Zoologicheskii Zurnal 90 (3): 368-376. [In Russian]

Rabotnov T.A. 1992. The phytocoenology. Moscow: Publisher of the Moscow State University. 351 p. [In Russian]

Rabotnov T.A. 1950. Aspects of studies of composition of populations for phytocoenology aims. Problems of Botany 1: 465-483. [In Russian]

Ryabinina Z.N., Knyazev M.S. 2009. The guidebook to the vascular plants of the Orenburg Region. Moscow: KMK Scientific Press Ltd. 758 p. [In Russian]

Ryabinina Z.N., Linerova L.G., Ishkildin A.B. 2011. Astragals of the Southern Ural (in the Orenburg Region). Vestnik $O G U$ 12: 135-137 [In Russian].

Ryabinina Z.N., Linerova L.G., Mushinskaya N.I., Dorokhina O.A., Kolontaeva N.V. 2013. To the study of the flora of the ravine-gully near the village Majorskoe. In: Proceedings of the IV International Theoretical and Practical Conference "Problems of stability of bioresources: the theory and the practice». Orenburg: Publishing House OGAU. P. 135-145. [In Russian]

Stankov S.S., Taliev V.I. 1949. The guidebook to the higher plants of the European part of the USSR. Moscow: Sovetskaya nauka. 1150 p. [In Russian]

Flora of the European part of the USSR. Vol. 1-6. Leningrad, 1974-1987. [In Russian]

Flora of Siberia. Vol. 1-14. Novosibirsk: Nauka, 1988-1997. [In Russian]

Flora of the USSR. Leningrad: AS USSR, 1934-1960. [In Russian] Zharkikh T.L., Yasynetskaya N.I. 2009. A study of preferred feeding plants of Equids at the Reserve «Askania Nova». Equus: 194-206.

\title{
ОЦЕНКА КОРМОВЫХ ЗАПАСОВ ДЛЯ ЛОШАДИ ПРЖЕВАЛЬСКОГО EQUUS FERUS PRZEWALSKII НА УЧАСТКЕ «ПРЕДУРАЛЬСКАЯ СТЕПЬ» ОРЕНБУРГСКОГО ЗАПОВЕДНИКА
}

\author{
Т. Л. Жарких ${ }^{1}$, Л. Г. Линерова ${ }^{2}$ \\ 'Заповедники Оренбуржья, Россия \\ e-mail: russian969@yandex.ru \\ ${ }^{2}$ Оренбургский государственный педагогический университет, Россия \\ e-mail: linerova.liuba2009@yandex.ru
}

\begin{abstract}
В 2015 г. в ФГБУ «Заповедники Оренбуржья», на территории степного участка «Предуральская степь» начата реализация Программы создания полувольной популяции лошади Пржевальского Equus ferus przewalskii. В 2014-2015 гг. на участке было проведено пилотное исследование, целью которого был выбор места для строительства Центра реинтродукции лошадей Пржевальского, оценка кормовых запасов на выбранной территории и выработка критериев оценки состояния растительности под влиянием выпаса. По результатам исследования было сделано заключение, что в пределах границ участка «Предуральская степь» Центр реинтродукции целесообразно разместить в урочище Курсай. В 2015 г. запасы кормов в урочище колебались от 14 ц/га в апреле до 30 ц/га в сентябре, при этом в травяном покрове абсолютно преобладали хорошо поедаемые лошадью Пржевальского виды, в частности, злаки, зарегистрировано значительное количество бобовых и поедаемого разнотравья. В будущем на данной территории необходим постоянный мониторинг состояния растительности под влиянием выпаса лошадей Пржевальского, при этом, с учетом вышеизложенного, критерием оценки должны быть 1) общая урожайность растительной массы; 2) динамика соотношения предпочитаемых и непоедаемых лошадью Пржевальского видов растений.
\end{abstract}

Ключевые слова: Equus ferus przewalskii, Заповедники Оренбуржья, кормовая емкость угодий, лошадь Пржевальского, Оренбургский заповедник. 